\section{Editorial ECTES Abstracts 2020}

\author{
Christine Gaarder $^{1}$ - Pål Aksel Næss ${ }^{1} \cdot$ Carlos Mesquita $^{2}$
}

Published online: 19 May 2020

(c) Springer-Verlag GmbH Germany, part of Springer Nature 2020

Dear colleagues and friends,

ECTES 2020 was to take place in Oslo, on April 26-28, and we had finalized a great program for what was going to be the most multidisciplinary ECTES to date.

The Corona virus outbreak first identified in China, in December 2019, spread to Europe, and was recognized as a pandemic by the World Health Organization (WHO) on March 11. Measures to achieve social distancing have been implemented at different time points and rates all over Europe, and the Norwegian Health Authorities decided mid March to cancel all major meetings at the congress venue until the end of April.

We are really sad and disappointed that we were not able to welcome you all in Oslo in 2020. The emergency surgical and trauma patient is in need of timely and competent care through the whole treatment chain, relying on broad based competence, multidisciplinary teamwork and communication. In a medical field moving towards increased subspecialization, it is easy to see how the quality of care of these patient groups could be challenged, and how many countries fail to implement or maintain their trauma and emergency medical systems.

ESTES is focusing on these important patient groups, the critically ill and injured surgical patients, with ECTES as the arena bringing personnel groups together in a multidisciplinary environment to improve, optimize, inspire, recruit, and provide possibility for networking and learning from each other.

ECTES is also the arena for presenting scientific work from all over the world. For ECTES 2020, we received nearly 700 abstracts. We are fully aware of how much effort

Christine Gaarder

TINGAA@ous-hf.no

1 Department of Traumatology, Oslo University Hospital

Ulleval, Oslo, Norway

2 Hospitais da Universidade de Coimbra, Coimbra, Portugal goes into this amount of scientific work. To all abstract authors-even if you are not going to be able to present your work as planned this year, we want to honor the effort made with this abstract book containing all accepted abstracts.

The ESTES Executive Board has decided to postpone the planned ECTES Congress in Ljubljana to 2022 and we are pleased to inform you that ECTES 2021 will take place in Oslo on April 25-27, exactly one year after the planned dates for ECTES 2020. Please help us make that an even greater event, hopefully celebrating the end of the Corona virus threat and providing an arena for exchange of lessons learned.

We are all busy in a very different way than we anticipated a couple of months ago. Our health care systems and institutions are being challenged more than ever. While there is naturally major focus on the management of Covid-19 patients at the moment and for a longer period ahead, the biggest impact on mortality and morbidity is likely to be in those patients unable to access specialist care because of lack of resources or because of less attention. We want to take the opportunity to remind everyone that we as trauma and emergency surgeons have a duty to secure the critically ill and injured, also through this period.

With this, we wish you great reading, stay safe and hope to see you all in Oslo 2021!

\section{Compliance with ethical standards}

Conflict of interest The authors declare that they have no conflict of interest. 